\title{
Teal Organizations: Literature Review and Future Research Directions
}

\author{
Barbara Wyrzykowska ${ }^{1}$
}

Submitted: 29.11.2019. Accepted: 2.01.2020

\section{Abstract}

Purpose: The article is a review aimed at presenting the concept of and available knowledge on teal organizations and at indicating further research objectives.

Methodology: Research methods employed in the study included a systematic review of the literature, along with its critical analysis and logical deduction.

Findings: The analysis shows that teal management - based on self-organization - may prove to be an opportunity for companies to adapt to changing circumstances. The teal organization concept is a true revolution in modern management, as it rejects all systems and previously immutable rules of the business world. The subject requires further empirical research.

Research limitations: Limitations apply to both the concept of teal organizations itself and the literature review. Since the teal organization concept was established in 2015, there is a lack of reviews and scientific studies or in-depth empirical research on this topic. Thus, the articles included in the review do not exhaust the issue.

Implications: The issues discussed in the article require further scientific research, primarily empirical. The said research should cover various aspects, such as building a culture of trust and self-organization, leadership (3.0), management through values, and new management methods.

Value: This is the first publication in this field that falls within this research gap. This study constitutes a significant contribution to the development of research on the concept of teal organizations.

Keywords: teal organizations, teal management model, self-organization, leadership, values

JEL: L21, D21, D22, D23

\footnotetext{
1 Warsaw University of Life Sciences - SGGW, Insitute of Managment, 166 Nowoursynowska St., 02-787 Warsaw, Poland, e-mail: barbara_wyrzykowska@sggw.pl, https://orcid.org/0000-0002-7025-0799. 
In work, we find the meaning of our life, the joy of creating and building a sense of dignity. - Prof. Andrzej Blikle

\section{Introduction}

Everything indicates that a revolution in management will happen in the next few years. Experts indicate that the approach to People Management undergoes changes (you employ a person, not an employee). This stems from the fact that employee engagement results from work meaning, motivation, leadership through partnership, and values. The working environment is changing: it should be simple, flexible, and employee-friendly. In this respect, the concept of teal organizations corresponds to labor market needs (Powichrowska, 2018, p. 102).

The author of the concept of teal organizations is Frederic Laloux (Laloux, 2015, p. 12-45). Most of his assumptions can serve as a very good source of inspiration for consciously initiating the process of change. In his book Reinventing Organizations, Laloux explains what a teal management model is, though he devotes relatively little space to how to achieve such a model. Therefore, we should consider what changes will be required in the organization management approach and how the role and functions of a leader in a teal organization should evolve.

The goal of the current article is to present the concept of and knowledge on teal organizations, but also to indicate further research directions. In order to achieve the intended result, the first part of the article presents the teal organization concept and a systematic review of existing research results. The second part proposes further empirical research based on the literature review; for example, related to building a culture of trust and self-organization, leadership (3.0), and value-based management in entities from various industries. The summary features conclusions on the development of the teal organization concept.

\section{Research Methodology}

The research methods used in this study are the systematic literature review (Czakon, 2011, p. 58; Mazur and Orłowska, 2018, p. 236-237), along with its critical analysis and logical deduction. The purpose was to identify current knowledge on teal organizations in Poland and abroad, and to indicate further directions for research. The following databases were used: EBSCO, ProQuest, CeON. A systematic search for literature began 
in January 2019 and analyzed articles published in 2015-2019. We searched through articles with the keywords: teal organizations, self-managing organizations, teal management model, teal management.

There are few texts in the literature on the subject devoted to teal organizations. The following journals were selected: Problemy Jakości (Problems of Quality), Problems of Quality, Przedsiębiorczość i Zarzq̨dzanie (Entrepreneurship and Management), Central and Eastern European Journal of Management and Economics, Coaching Review, Gospodarka Materiałowa i Logistyka (Materials Management and Logistics), Marketing i Rynek (Marketing and Market), Marketing i Zarzqdzanie (Marketing and Management), Przedsiębiorstwo \& Finanse (Enterprise \& Finance), Relacje. Studia z Nauk Społecznych (Relationships. Studies in Social Sciences), Studia i Prace Wydziału Nauk Ekonomicznych i Zarzqdzania US (Studies and Works of the Faculty of Economic Sciences and Management of Szczecin University), Zarzqdzanie i Finanse (Management and Finance), Zeszyty Naukowe Wyższej Szkoły Bankowej w Poznaniu (Science Journals of the Poznań School of Banking), Zeszyty Naukowe Organizacja i Zarzqdzanie (Scientific Journals Organisation and Management), Zarzqqdzanie Zasobami Ludzkimi (Human Resources Management), Personel i Zarzqdzanie (Staff and Management). Published books were also included from such authors as Laloux (2015), Sinek (2018), De Marco and Lister (2002), Collins (2018), Morgan (2014), Jeznach (2017).

\section{The Teal Organization Concept}

It is difficult to clearly establish the beginning of organizations functioning according to the teal idea. Entrepreneurs who describe their organizations as teal often declare that they did not know their approach to employees and management fits the teal idea (Holwek, 2018, p. 19-28).

When trying to determine a specific date when teal organizations appeared, we should reach for the works of Edwards Deming from 1950-1970 (Deming, 1995, p. 23) and Peter Drucker (Drucker, 1999). It was then that the so-called 14 Deming Principles were published, which offer tips for companies that face changes in their environment. Among other things, the principles cover aspects related to quality, human capital management, and building lasting relationships with suppliers. The 14 Deming Principles form the basis of the US industry's transformation. It is not enough to solve problems, however large or small. Only the adoption and implementation of the 14 Deming Principles is a signal that the company's management intends to survive on the market and protect the interests of both owners and employees. Moreover, this system served 
as a learning base for managers of Japanese companies in 1959 and later. The 14 Deming Principles apply everywhere: in small and large organizations, in service-oriented and manufacturing companies, but also in internal departments of a company.

The year 2015 was a breakthrough for the contemporary perception of teal because of the book Reinventing Organizations, published by Frederic Laloux. It is when the idea of teal organizations gained renown. The book proved that a new approach to management was possible, one based on respect for and trust in people, while arguing that this new approach increases enterprise efficiency (Laloux, 2015, p. 58-59).

Analyses of teal organizations are based on the classification of companies presented by Laloux, who believes that teal is the result of the labor model's evolution, as - throughout history - people were to go through five major stages of management. Laloux distinguishes four types of organizations that can be observed on the market - from the most authoritarian to the most democratic ones - along with a fifth one being the most effective from the perspective of interpersonal cooperation. He assigns each of the types a different color. The first type is to be red, in which management over subordinates is conducted by one person by instigating fear in other members of the firm. The amber style has many managers in a strictly defined hierarchy. The next one is the most popular type, orange, which also is a hierarchical organization that focuses on profit. Employees are treated as "cogs in a machine" that must complete their tasks. The fourth type is green, with a concept similar to teal, because it bases its management on certain values, but a hierarchical approach is still enforced in these organizations. The fifth type is teal, which is completely separate from all the previous styles (Laloux, 2015, p. 21-68).

Laloux sees the future of management in teal. He identifies several paradigms that characterize this type, with the following being the most important ones (Laloux, 2015, p. 45-73):

- Supervision over employees should be limited, because employees are capable of self-control. The manager is a colleague. His role changes. He is becoming a mentor, a leader.

- Organizations have a flexible organizational structure, which is adapted to current tasks. The person with the most knowledge in a particular field is the leader. Depending on the needs, roles are exchanged between the people who form the organization.

- Management is based on trust, both in employer-employee and employee-employee relations. 
- Knowledge is the primary resource of a teal organization. Every problem is an opportunity to learn and reach a higher level. The company must establish effective methods of knowledge exchange between teams. Internal and external communication is necessary to assure the effectiveness of these processes.

The concept of a teal organization assumes that effective actions are possible without a formal hierarchy, without a formal incentive system. Self-regulation and self-management are the key elements. Building a teal organization is based on three complementary paradigms (Blikle 2018, p. 34-45):

1. teal work culture;

2. teal organization structure;

3. teal quality culture.

Frederic Laloux also lists the priorities that serve as the base for creating teal organizations (Laloux, 2015, p. 276-278):

1) self-management, i.e. the ability of team members to self-manage, take responsibility, and flexibly adapt to current challenges;

2) wholeness, i.e. a feeling that people can be themselves at work, be accepted as they are, with separation of professional and private life being superfluous;

3) evolutionary purpose, i.e. the company's mission and vision, but from the company's perspective, as a living and changing organism with a purpose of life, with team members helping to achieve it every day;

4) transparency, which refers to sharing important strategic information with all the people in the company, e.g. informing of the financial or business situation.

The companies described by Laloux in his book and those from Poland develop very similar organizational principles, without knowing each other or referring to a common model. They arrived at these principles by assuming that people are most effective in an environment of freedom, trust, partnership, and co-operation.

Many modern organizations fail to even fit into the assumptions of the green paradigm, and they are certainly distant from the teal model (Holwek, 2018, p. 28-25). The transformation of a traditional company into a teal company entails a profound social change in the company and individual transformation in each employee (Pluta, 2016, p. 107-120). Becoming a teal organization takes time and effort, it is not an easy and quick process, but it is possible. This can be demonstrated by Polish companies such as Mentax.pl, Brewa, Kamsoft Podlasie, Marco, Coder Center, Sodexo, Masterpress, 
the Leance kindergarten chain, Notjustshop, and the mineral water manufacturer Spółdzielnia Pracy „Muszynianka” (Blikle, 2017). We find such changes among foreign companies such as Morning Star, AES that operates in energy production and transmission with 40,000 employees, BSO/Origin in the IT industry with 10,000 employees, the Dutch organization of social nurses Buurtzorg with 8,000 employees, or the German ESBZ school with 1,500 students and teachers (Laloux, 2015).

Teal organizations are unlike any previously known organizational model, which is why they garner the interest of experts in business management and scientists. Teal is a fascinating phenomenon and - perhaps - our future, but it currently is a large experiment. There are too few teal organizations to draw far-reaching conclusions, and these organizations are practically marginal (Holwek, 2018, p. 15-30).

\section{Review of Existing Study Results}

The literature review is an important part of any scientific project (Webster and Watson, 2002, p. 13). The concept of teal organizations appears increasingly often, mainly in Polish literature, and becomes the subject of a wider discussion (including Bartosiewicz, 2017; Galat, 2018; Iwko and Pisarska, 2019; Kirov and Kirova, 2017; Kozina and Pieczonka, 2017; 2018; Mażul, 2016; Pluta, 2016, 2017; Powichrowska, 2018; Rosiński, 2018; Sypniewska and Baran, 2019; Tabaszewska-Zajbert and Sokołowska-Durkalec, 2018; Ziębicki, 2017). Recent years saw the growth of research on teal organizations (Blikle, 2014; 2015; 2016; 2017; 2018; Dudziuk and Rybarczyk, 2017; Laloux, 2015; Holwek, 2018; Hopej-Tomaszycka and Hopej, 2018; Kalwa-Rojczyk, 2018; Skrzypek, 2017; Zygadło, 2018).

Table 1 presents a summary that organizes literature around issues related to teal organizations, which also shows that relevant literature is highly limited.

Past considerations and empirical research focus mainly on the evolution of teal organizations and their relationship with Ken Wilberg's integral theory and the evolutionary model of consciousness development (Laloux, 2015; Holwek, 2018; Galat, 2018; Rosiński, 2018; Bartosiewicz, 2017). The Integral Theory is an attempt to bring together and arrange civilizational assets such as scientific, philosophical, and spiritual approaches into a holistic, dynamic image the All Quadrants All Levels (AQAL model), which allows for a comprehensive understanding of the surrounding reality and its phenomena and a more effective functioning in the world. It is a meta-paradigm that organizes the paradigms of individual knowledge fields. 
Table 1. Selected aspects of teal organizations analyzed in the literature

\section{Authors}

Laloux, 2015; Holwek, 2018; Galat, 2018; Rosiński, 2018; Bartosiewicz, 2017

Morgan, 2014; Laloux, 2015; Blikle, 2014, 2015, 2017, 2018; Jeznach, 2017; Ziębicki, 2017

Kirova, 2017; Kirov, 2017; Sypniewska, Baran, 2019; Sinek, 2018; Baczyńska, Korzyński, 2017

Laloux 2015; Hopej-Tomaszycka, Hopej 2018; Skrzypek, 2017;

Collins, 2018

Powichrowska, 2018;

Blikle, 2017

Zygadło, 2018; Pluta, 2016;

Galat, 2018

DeMarco, Lister, 2002;

Iwko, Pisarska, 2019;

Tabaszewska-Zajbert,

Sokołowska-Durkalec, 2018

Kalwa-Rojczyk, 2018;

Galat, 2018; Zaleśna, 2018

Mażul, 2016; Kozina,

Pieczonka, 2018; Kozina,

Pieczonka, 2017; Galat, 2018

Dudziuk, Rybarczyk, 2017

\section{Aspects pertaining to a teal organization}

1. The evolution of teal organizations. The evolutionary model of consciousness development (based on Ken Wilber's Integral Theory) and perspectives for organizational development (based on Wilber's Squares); Spiral Dynamic concept; Psychological approach.

2. Rules and trends related to the future of management and organization functioning; organization types (colors), differences between them (strengths/weaknesses), examples of teal organizations; models, principles, and operational methods; interpersonal relations; method of implementing "Total Quality Management - (TQM)" self-organization process model.

3. Talents and leadership, the role of a leader, leadership 3.0, leadership competencies among managers.

4. Organizational structures and rules for creating teal organizations.

5. Management concept (sharing knowledge), trust.

6. Empowerment and commitment of employees in self-managing organizations; employee values and values in the organization.

7. Motivation, commitment, and impact of the environment on employees (workplace, conditions, processes, teamwork, motivation); personal function and the role of coaching in a teal organization.

8. The functioning of teal organizations within the scope of employee competencies; trends on the labor market: the entering to the labor market of new generations (X, Y, Z).

9. Communication in managing a teal team; teal approach to conflict management; negotiations in a teal organization; barriers to creating teal organizations.

10.Teal organizations and decision-making in a company as a key element of proper management and flow of goods and rendered services.

Source: own elaboration.

Organisms, behaviors, systems, and cultures evolve and our consciousness finally evolves along all development lines, among which we most often distinguish cognitive, emotional, ethical, spiritual, and psychomotor. Evidence for this appear in how interest 
in evolution rapidly increased in various fields of science and an increasing number of studies on this subject (Graves, 1970). The most renowned researchers of the evolution of consciousness are Jean Piaget (cognitive development), Lawrence Kohleberg, Carol Gilligan (moral development), Abraham Maslow (the evolution of needs), Susanne Cook-Greuter, Robert Kegan, Bill Torbert (evolution of leadership), Clare Graves, Don Beck, Christopher Cowan (evolution of needs, values, identity, ego development), and Michael L. Commons (development of employee competencies).

In his description of organizations, Laloux makes reference to the Spiral Dynamic (SD), which is a model that describes the evolution of societies and individuals, cultures and value systems in response to changing living conditions. This evolution follows a route from simpler to increasingly more complex systems (values, beliefs, sense of identity, needs). SD is a concept of the evolution of consciousness first described by Clare Graves (1965), later expanded by Don E. Beck and Chrisopher Cown (1996), which - after Ken Wilberg's (1997) adaptations - became one of the key tools in integral theory. According to Laloux's (2015) model, changes in how companies operate are a natural process shaped by changes in the level of awareness of people's needs. What Laloux deems to be common for all "teal organizations" - developed in different ways and under very different circumstances - is this "teal" (or integral) level of awareness common to their leaders, which constitutes the source of transformation of organizations under their management.

According to Holwek (2018), these leaders act in accordance with prescribed values, their calling to do something good and meaningful for the world, which is more important to them than the pursuit of profit, material goods, status, career, or the satisfying of an egotistical need for power, control, and achievements. Blikle (2014) claims that a manager in a teal organization becomes a leader and his most important tasks include:

1) building a space for dialogue;

2) building partnership and trust;

3) building co-operation;

4) supporting the teal ten commandments;

5) being a role model.

The primary feature of teal organizations is their new approach to management. Teal organizations are based on a flat organizational structure, in which there is no hierarchy, and the classic motivation system is replaced by their employees' internal motivation (Hopej-Tomaszycka and Hopej, 2018; Skrzypek, 2017; Collins, 2018). Based on his research, Laloux (2015) distinguishes three types of structural solutions in teal organizations: 
parallel teams, a "web of individual contracting," and "nested teams." In organizations studied by Laloux, their presidents and founders remain active and embody a moral authority. They must serve as role models, which refers to the three principles of self-management, wholeness at work, and evolutionary purpose (Laloux, 2015). Managerial positions are abolished in teal organizations, but those who previously performed them retain their roles of leaders, mentors, or mediators (Sypniewska and Baran, 2019, p. 131-136).

Moreover, the analyses of organizational structures of teal organizations (Hopej-Tomaszycka and Hopej, 2018) show that these are flexible solutions, which contrary to Laloux (2015), are not disruptive in nature, as they are not devoid of hierarchical dependencies; albeit the dependencies present among these organizations are not strong. Moreover, teal organizations exhibit a certain level of bureaucracy, which increases their complexity. The aforementioned authors believe that teal organizations have limited application in management practice, because they are based on a very optimistic image of people, one in which they do not strive to dominate others.

Teal organizations result from the evolution of the knowledge management concept (Powichrowska, 2018). Knowledge is the basic resource of teal organizations. Aside from the knowledge necessary to perform activities in their main area of specialization, employees must demonstrate general knowledge that allows them to perform in different positions, should such a need arise (Paliszkiewicz, Gołuchowski and Koohang, 2015, p. 19-35). Creating, but mostly managing knowledge teams, is another challenge. Blikle (2015) states that decisions in a teal organization are made by those with knowledge, and others trust them.

The teal organization concept sets a new paradigm of the so-called self-managing organization. This paradigm is based on employee empowerment, giving them a sense of importance and significance of what they do in the company (Skrzypek, 2017, p. 2). In a teal organization, individuals set their own responsibilities and choose projects in which they wish to participate. Every member of a team must demonstrate creativity and commitment, because they are responsible for the project. The transfer of power to employees is key, but it also is the most controversial pillar of the teal concept. Employees have specific tasks that are governed by the following principles (Blikle, 2017, p. 5):

1. you do what you can;

2. you do what is needed;

3. you are responsible for what you do;

4. you can change what you do, but always respecting principles 1, 2, and 3 . 
Another distinctive aspect of this type of organization is the lack of a formal motivation system, as noted by DeMarco and Lister (2002), Iwko and Pisarska (2019), Tabaszewska-Zajbert and Sokołowska-Durkalec (2018), which consists in a total renouncement of all kinds of bonuses, commissions, promotions, but also orders, competition, or periodic performance reviews. It is a model that requires a significant level of maturity and commitment from employees.

Companies that wish to introduce teal ideas in already functioning teams should ensure the development of new competencies and skills among their members (Kalwa-Rojczyk, 2018; Tabaszewska-Zajbert and Sokołowska-Durkalec, 2018), such as:

- peer feedback: soliciting, giving and receiving feedback from colleagues;

- peer coaching: the ability to support colleagues, share knowledge, and use feedforward sessions;

- team problem-solving: the ability to draw conclusions from one's own experiences and to learn to create new and better solutions (e.g. by using the Design Thinking method);

- team resolution of internal conflicts;

- team decision-making;

- interpersonal skills and the ability to work in a team.

Frederic Laloux states that the teal organization management model is the next stage in development that results from human consciousness. Considering that new generations (Gen Y and Gen Z) enter the labor market with a different work ethos, value system, and modes of action, among other factors, it is hard to disagree with Laloux. According to Galat (2018, p. 35-36) an analysis of the foundations of teal organizations shows that they are the answer to the changing reality, and they seek to fulfill the workplace expectations of both generation $\mathrm{Y}$ and $\mathrm{Z}$. This stems from the fact teal organizations allow for individualism, value creativity, and seek to make each employee feel special. Moreover, the ability to make decisions increases employee commitment and gives them a sense of creating the organization instead of performing entrusted tasks (Dudziuk and Rybarczyk, 2017).

Importantly, in teal organizations, profit is never an end in and of itself (Jeznach, 2017, p. 7-36). Organizations based on this model do not operate pursuant to plans with implementation scheduled for a specific period of time. They are flexible and adapt to their market reality. 


\section{Research Limitations}

This study is not devoid of limitations, which apply to both the concept of the teal organization itself and the literature review. Since the teal organization concept was established in 2015, there is a scarcity of reviews, scientific studies, and in-depth empirical research on this topic. The articles included in the review do not exhaust the issue of teal organizations.

Teal organizations engender many challenges. To create or reorganize a company is a difficult and lengthy process. Limitations appear as both internal factors - e.g. the approach of management or prevailing stereotypes about work and employees - and external factors, on which individual organizations have less influence. The full diagnosis of a reorganization to the teal model would require a consideration of all internal and external organization constraints.

Business practice increasingly employs self-management and related concepts. Such solutions are used mostly in modern companies with a focus on dynamic development, which seek new working methods and more effective management. That is, self-management occurs primarily in creative organizations like scientific teams, artistic teams, construction offices, editorial teams, and advertising agencies. Such organizations are conducive to shaping creative environments that, in turn, favor the growth of co-operation and the creation of shared values. Nevertheless, the teal approach should be treated as a lasting trend in management, which is never universal. Teal management cannot be implemented in all conditions. In particular, this approach cannot be applied in traditional industries, in which enterprises strive for stability and reliability.

A further limitation to implementing self-management is the need for employees to have high competencies, which allows them to assume various roles and act effectively without a leader. Therefore, self-management should be considered an alternative to the traditional management model, with the latter probably remaining dominant for a long time.

The concept of Graves' value levels (Graves, 1970) is a complex theory, which requires extreme openness, for example, from managers. Therefore, its application in research, for example, on management styles is difficult both in terms of methodology and substantive aspects, such as for a research group to understand its assumptions. 


\section{Future Research Suggestions}

The issues discussed in the article require further scientific research, primarily empirical. This research should cover various aspects, such as building a culture of trust and self-organization, leadership (3.0), management through values, and new management methods.-

Within this scope, the key research problem is the assessment of the effectiveness of replacing a traditional management approach with forms of self-organization. Combined research in this field may consist in comparing the management effectiveness in enterprises of an identical type, with some using a traditional approach to management and others implementing forms of self-organization. Another significant research problem is that of a cognitive nature, which means identifying the extent and degree of self-organization in business practice. This can be combined with studies of methodological aspects of implementing self-organization and its forms. The abovelisted research problems were not the subject of broader scientific research until now (Ziębicki, 2017, p. 80-89).

Management by values is another research challenge. The term "employee values" is not yet in wide use, as demonstrated by the limited number of articles appearing in the query for the keyword "employee value" in databases such as ProQuest or Ebsco. Recently, many studies appeared that cover employee expectations and the perception of these expectations by persons who manage organizations or are responsible for HR. These studies show that there is a gap between what employers deem important for employees and what the latter consider real value for them, which affects their satisfaction and willingness to stay in a given company. The idea of employee values is an increasingly interesting research area for scientists, but it also is the subject of consideration for managers of entities that operate on the market (Rudawska, 2015, p. 395). For a modern manager responsible for employee development, it is of key importance to understand what value systems their employees follow and to be able to use this knowledge in the transformation process (Czop, 2014, p. 69-81).

Therefore, it seems justified to conduct empirical research as the next step in understanding the implications of self-leadership for the management paradigm within a Spiral Dynamics context. Changes in the management paradigm are the result of social circumstances, economic changes, which periodically place new demands on organizations and managers. The dynamics of new management paradigms are an area researched by many scientists (cf. Czarkowska, 2012). Concepts such as Wilberg's Integral theory (2006) and Beck and Cown's spiral dynamics (1996) refer to the growth of 
collective consciousness, a systemic and holistic perception of life and the world. They are based on the theory of human consciousness development levels, formulated over many years of research in the 1970s by Clare W. Graves (Graves, 1970). Despite 45 years since its publication, Graves' research still remains valuable and useful. It is widely used in the context of political and cultural conflicts, recently also in business and management (Cacioppe and Edwards, 2005). Spiral Dynamics describes value systems and a perception of the world as an effect of the interaction of living conditions and intellectual abilities. The idea assumes that everyone has a comprehensive, adaptive, contextual intelligence that develops in response to life's circumstances and challenges. These are the living conditions that affect the appearance of subsequent levels of consciousness and the formation of collective intelligence at each of them referred to as "memes."

Self-leadership (leadership 3.0) is part of a new paradigm of holistic management-management through values. Management 3.0 means innovation, leadership, and the highest level of management. Management 3.0 redefines leadership by describing management simply as a group responsibility. This refers to cooperation focused on finding the most efficient way to achieve business goals through employee satisfaction, which Management 3.0 prioritizes. The holistic approach is a comprehensive approach. It manifests itself in the belief that all phenomena in the universe combine into holistic systems subject to certain regularities, systems that should not be judged by the regularities that govern their constituent parts. In other words, the holistic approach assumes that the whole is not equal to the sum of its parts. The concept is derived from the Greek word holos, which means "whole." One of the manifestations of this paradigm is the coaching management style, which is increasingly often used in organizations. The coaching management style assumes, first and foremost, a high level of awareness on the part of the manager, who should be 1) open to feedback on his competencies and attitudes, 2) strive for continuous self-improvement, and 3) be ready to replace a management paradigm characterized by supervision, control, and monitoring with a new approach that demonstrates a high level of communication, taking into account the employee's perspective, delegating responsibility, and a lower level of control.

The focus on deep values and the resulting implications for management strategies requires further development (Covan and Todorovic, 2000), especially when taking into account that managers's value systems differ from employee values. According to Graves, one may even be tempted to state that employees often are at a higher level of value systems than their bosses (Graves, 1965).

The management sciences lack a holistic approach that would take into account the needs, values, and goals of the organization, its managers, and its employees. 
A theoretical concept that makes a big contribution to its development is the integral theory along with Spiral Dynamics. The two form the basis for the development of a new approach to leadership called integral leadership. This theory gives the leader a "map," making it easier to understand the complex reality, the people they lead, but also their world and the values they face. Integral leadership enables the improvement of one's own managerial competencies that meet organization needs, but it also acts as a source of inspiration and knowledge on motivating others. Recently emerging leadership theories/ideas partially explain the essence of this phenomenon, but they only emphasize certain aspects. The integral leadership theory provides the need and opportunity to take a holistic view of leadership.

\section{Contribution to the Development of Management Science}

Developing the teal concept in management sciences is an important part of modern knowledge. Even though this issue recently became a point of interest for scientific discourse, reviews and comprehensive research are lacking. This is the first review publication in this field that falls within this research gap. Hence, this study constitutes a significant contribution to the development of research on the teal organization concept.

Based on a systematic review, the article organizes existing knowledge and creates a firm basis for the development of new knowledge. Moreover, the current article facilitates theoretical development and discovers areas in which further research is needed (Webster and Watson, 2002, p. 13).

Knowledge gained through the literature review leads us to the indication of guidelines for further research in this field. Furthermore, this knowledge serves as an explanation of the teal organization concept, aimed at improving the level of knowledge of scientists and help practitioners in its implementation.

\section{Summary and Conclusions}

Five years passed since the publication of Laloux's book in 2015 and his publication - but also the described specific self-organization and self-management practices - inspired an increasing number of entrepreneurs to change the way they conduct management in their companies. This emerging new company organizational model based on self-management, self-organization, trust, and a departure from directive-based management can inspire many more organizations. 
The development of the teal organization concept requires action not only at the level of scientific research but also business practice. This will enable the effective implementation of teal concepts in enterprises in the future (Powichrowska, 2018, p. 103).

The teal model is an extremely democratic management method. Moreover, it is a model that requires a significant level of maturity and commitment from employees. Currently, not every company is ready for such a revolutionary transformation of its functioning. However, individual solutions can be implemented in most organizations gradually; for example, by introducing greater autonomy in decision-making and activities in teams. Creating teal teams has two conditions:

1. the mature awareness of managers able to relinquish some of their rights to the team and empower people;

2. the development of employee skills, so that they can manage themselves.

Teal organizations only begin to manifest themselves in the socioeconomic reality. They are a breath of fresh air in how organizations are managed. There is no other organization management model that would rely on human nature as much as teal. Human capital management will be of great significance in "Evolutionary Teal," which may become an interesting niche for implementation in a few years.

\section{$\underline{\text { References }}$}

Baczyńska, A. and Korzyński, P. (2017). Leadership Competencies Among Managers. Journal of Management and Business Administration. Central Europe, 2, 6-22,

https://doi.org/10.7206/jmba.ce.2450-7814.193.

Bartosiewicz, S. (2017). Turquise Companies, Future or Utopia? Central and Eastern Journal of Management and Economics, 5(3), 393-397.

Beck, D. and Cowan, Ch. (1996). Spiral Dynamics: mastering Values, Leadership, and Change. Blackwell Publications: Malden, MA.

Blikle, A. (2014). Kompendium turkusowej organizacji, http://www.moznainaczej.com.pl/Download/Turkus/A.Blikle_Kompendium_turkusowej_ samoorganizacji.pdf (14.05.2019).

Blikle, A. (2015). Demokracja partnerska, http://www.moznainaczej.com.pl/artykuly-wlasne/demokracja-partnerska (23.06.2019).

Blikle, A. (2017). Organizacje turkusowe w Polsce, http://www.moznainaczej.com.pl/organizacje-turkusowe-w-polsce (10.02.2019).

Blikle, A. (2018). Doktryna jakości, Wydanie II turkusowe (Rzecz o turkusowej samoorganizacji, https://(www.moznainaczej.com.pl/Download/DoktrynaJakosci/DoktrynaJako\%C5\%9Bci_ wydanie_II.pdf (23.07.2019).

Collins, J. (2018). Od dobrego do wielkiego. Czynniki trwałego rozwoju i zwycięstwa firm. Warszawa: MT Biznes. 
Cowan, Ch. and Teodorovic, N. (2000). Spiral dynamic. Strategy\&Leadership, 28(1), 4-12, https://doi.org/10.1108/10878570010335912.

Czakon, W. (ed.) (2016). Podstawy metodologii badań w naukach o zarzqdzaniu. Warszawa: Wydawnictwo Nieoczywiste.

Czarkowska, L.D. (2012). Zarządzanie zintegrowane i coachingowe. Pierścień transformacji jako narzędzie rozwoju świadomości. In: L.D. Czarkowska (ed.), Coaching jako wskaźnik zmian paradygmatów w zarzq̨dzaniu. Warszawa: Poltext.

Czop, K., (2014). Zdolność organizacji do wprowadzania zmian i jej wpływ na proces zarządzania zmianą. Zeszyty Naukowe Politechniki Częstochowskiej, 24(2), 69-81, https://doi.org/10.17512/znpcz.2016.4.2.07.

De Marco, T. and Lister, T. (2002). Czynnik ludzki. Skuteczne przedsięwzięcie i wydajne zespoły. (Peopleware: Productive Projects and Teams). Warszawa: Wyd. Naukowo-Techniczne.

Deming, E.W. (1995). Out of Crisis, Massachusetts Institute of Technology. Center for Advanced Engineering Study, MIT Cambridge.

Drucker, P. (1999). Management Challenges for the 21st Century, Classic Drucker Collection. Soundview Executive Book Summaries 10 LaCrue Avenue, Concordville, Pennsylvania.

Dudziuk, I. and Rybarczyk, A. (2017). Analiza ścieżki decyzyjnej i jej implementacja w środowisku małego i średniego przedsiębiorstwa. Gospodarka Materiałowa i Logistyka, 12, 136-143.

Galat, W. (2018). Turkusowe organizacje odpowiedzią na wyzwania rynku pracy. (Teal organizations as an answer to challenges on the labor market). Zeszyty Naukowe Wyższej Szkoły Bankowej ${ }_{w}$ Poznaniu (Scientific Journal of the WSB University in Poznań), 82(5), 35-43.

Graves, C.W. (1965). Value Systems and relation to Managerial Controls and Organization. https://ostromworkshop.indiana.edu/library/node/73462 [accessed on: 12.09.2019], https://doi.org/10.1177/002216787001000205.

Graves, C.W. (1970). Levels of Existence: An Open System Theory of Values. Journal of Humanistic Psychology, 10, 131-155.

Graves, C.W. (2005). The never-ending quest: Clare W. Graves explores human nature. Santa Barbara: ECLAT Publishing.

Gutkowski, M. and Holwak, J., Integralne przywództwo w świecie VUCA, http://wilber.pl/media/pdf/Integralne\%20Przyw\%c3\%b3dztwo\%20w\%20\%c5\%9bwiecie\%20 VUCA.pdf (20.09.2019).

Holwek, J. (2018). Dajmy już spokój z tym turkusem. O tym, jak piękna praktyka staje się modą, a nawet ideologią. Coaching Review, 1(10), 11-30, https://doi.org/10.7206/cr.2081-7029.56.

Hopej-Tomaszycka, M. and Hopej, M. (2018). Struktury organizacyjne turkusowych organizacji. Zeszyty Naukowe. Organizacja i Zarzqdzanie, 130, 233-242, https://doi.org/10.29119/1641-3466.2018.130.20.

Iwko, J. and Pisarska, A. (2019). Realizacja funkcji personalnej w organizacji turkusowej. Problemy Jakości, 51(4), 2-10, https://doi.org/10.15199/46.2019.5.1.

Jeznach, A. (2017). Szef, który ma czas. Gliwice: Wydawnictwo Helion.

Kałwa-Rojczyk, A. (2018). Funkcjonowanie turkusowych organizacji w kontekście kompetencji pracowniczych. Studia i Prace WNEiZ US, Problemy współczesnej ekonomii, 51(2), 45-54, https://doi.org/10.18276/sip.2018.51/2-04.

Kirov, N. and Kirova, N. (2017). Do „turkusu” trzeba dojrzeć! Czyli gdzie zaczyna się świadome przywództwo? Personel i Zarzqdzanie, 10, 18-23.

Kirova, N. (2017) Talenty lidera: jak stać się świadomym przywódcą? Personel i Zarządzanie, $11,64-67$. 
Kozina, A. and Pieczonka, A. (2017). Negocjacje w turkusowej organizacji. Zarzqdzanie i Finanse, 15(2), part 1, 163-176, https://doi.org/10.18276/miz.2018.51-20.

Kozina, A. and Pieczonka, A. (2018). Turkusowe podejście do zarzq̨dzania konfliktami organizacyjnymi. Marketing i Zarządzanie, 1(51), 207-214.

Laloux, F. (2015). Pracować inaczej. Warszawa: Wyd. Studio EMKA, https://doi.org/10.15358/9783800649143.

Mażul, E. (2016). Czerwień czy turkus: opresyjna i nieopresyjna komunikacja w zarządzaniu zespołem. Personel i Zarzqdzanie, 12, 48-51.

Mazur, Z. and Orłowska, A. (2018). Jak zaplanować i przeprowadzić systematyczny przegląd literatury. Polskie Forum Psychologiczne, 23(2), 235-251.

Morgan, J. (2014). The Future of Work, Amazon Digital Services. Wiley.

Paliszkiewicz, J., Gołuchowski, J. and Koohang, A. (2015). Leadership, trust, and knowledge management in relations to organizational performance: Developing and instrument. Online Journal of Applied Knowledge Management, 3(2), 19-35.

Pluta, A. (2016). Organizacja turkusu - możliwości i problemy wdrożeni. Kapitał Ludzki - Rozwój Ku Wartościom, 10/2016, 107-126.

Pluta, A. (2017). Kanon wartości pracowników i wartości organizacji, jako podstawa do wdrożenia koncepcji Organizacji Turkusu. Marketing i Rynek, 4, 304-315.

Powichrowska, B. (2018). Od zarządzania wiedzą do zarządzania w kolorze turkusu. Przedsiębiorstwo \& Finanse, 1, 95-104.

Rosiński, J. (2018). Creating an Evolutionary Teal Organization on a Step-by-step Basis. A Case Study. Przedsiębiorczość i Zarzq̨dzanie, 19(6), 243-256.

Rudawska, E. (2015). Koncepcja wartości w relacjach pracownik-organizacja (The idea of values in employee-organization relations). Zeszyty Naukowe Uniwersytetu Szczecińskiego, 39(2), 393-405.

Sinek, S. (2018). Zaczynaj od dlaczego. Jak wielcy liderzy inspiruja innych do działania. Warszawa: OnePress.

Skrzypek, A. (2017). Organizacja turkusowa - szansa na nową jakość zarządzania czy utopia? Problemy Jakości, 49(12), 2-9, https://doi.org/10.15199/48.2017.12.1.

Sypniewska, B. and Baran, M. (2019). Konferencja „Przyszłość HR z perspektywy nauki i biznesu. Przywództwo 3.0”. Zarzq̨dzanie Zasobami Ludzkimi, 1, 131-136.

Tabaszewska-Zajbert, E. and Sokołowska-Durkalec, A. (2018). Coaching jako narzędzie wsparcia turkusowego modelu organizacji. Przedsiębiorczość i Zarzq̨dzanie, 19(8), 617-629.

Webster, J. and Watson, R.T. (2002). Analyzing the Past to Prepare for the Future: Writing a Literature Review. MIS Quarterly, 26(2), 13-23.

Wilberg, K. (1997). The Eye of Spirit: An Integral Vision for a World Gone Slightly Mad. Shambbala, Publication Boston.

Wilberg, K. (2000). Integral Psychology: Consciousness, Spirit, Psychology, Therapy. Shambbala, Publication Boston.

Wilberg, K. (2006). Integralna teoria wszystkiego. Wizja dla biznesu, polityki, nauki i duchowości. Poznań: Zysk i Spółka.

Wright, S. (2008). An Exploration of Integral Leadership, http://www.thecoachingproject.com/wpcontent/uploads/Introduction_to_Integral_Leadership. pdf (20.09.2019). 
Zaleśna, A. (2018). Oczekiwania pracowników różnych pokoleń dotyczące wybranych elementów społecznej odpowiedzialności pracodawcy. Przegląd Organizacji, 4, 46-50, https://doi.org/10.33141/po.2018.04.07.

Ziębicki, B., (2017). Organizacje bez „szefów” - współczesna moda czy nowy paradygmat zarządzania? Humanizacja Pracy, 4, 80-90.

Zygadło, A. (2018). Poczucie podmiotowości i zaangażowanie pracowników we współczesnych samozarządzających się organizacjach. Relacje. Studia z Nauk Społecznych, 5, 151-160. 